\title{
Photoelectrochromic windows and displays
}

\author{
Clemens Bechinger*, Suzanne Ferrere, Arie Zaban, \\ Julian Sprague \& Brian A. Gregg
}

National Renewable Energy Laboratory, 1617 Cole Boulevard, Golden, Colorado 80401-3393, USA

Рнотоснвоміс materials ${ }^{1,2}$ change colour on absorption of light, whereas electrochromic materials ${ }^{3,4}$ change colour in response to an electrically induced change in oxidation state. Both classes of materials are being investigated for potential applications in displays, imaging devices and 'smart' windows ${ }^{5-8,15,16}$. Here we describe an alternative route to such applications, in which an electrochromic film and a photovoltaic film form the two electrodes of an electrochemical cell. The resulting structure exhibits photochromism, but unlike conventional photochromic films, the light-absorption process (in the photovoltaic film) is separate from the coloration process (in the electrochromic film): both may therefore be optimized individually. Moreover, as the coloration process in our cells requires an external electrical current between the two electrodes, the optical state of the celltransparent, absorbing or, in the case of non-uniform illumination, patterned-can be stored when the circuit is open, or changed when the electrodes are connected.

The light-absorbing function in the photoelectrochromic (PEC) cell is performed by a dye-sensitized semiconductor electrode that produces a photovoltage sufficient to colour the electrochromic film deposited on the counter electrode. Dye-sensitization has a long history of use in colour photography and is currently being studied as a potential means of solar energy conversion ${ }^{9-11}$. Some of the best-known electrochromic materials are inorganic oxides such as $\mathrm{WO}_{3}$ and $\mathrm{MoO}_{3}$. We illustrate the principle of the photoelectrochromic cells with a ruthenium polypyridine-sensitized nanocrystalline $\mathrm{TiO}_{2}$ electrode, similar to those introduced by Grätzel et al. for use in solar cells ${ }^{9,10}$, and a $\mathrm{WO}_{3}$ electrochromic film on the counter electrode.

The dye, $\mathrm{Ru}(\mathrm{n}) \mathrm{L}_{2} \mathrm{~L}^{\prime}$, where $\mathrm{L}$ is $2,2^{\prime}$-bipyridine- $4,4^{\prime}$-dicarboxylate and $\mathrm{L}^{\prime}$ is $4,4^{\prime}$-dimethyl-2,2' -bipyridine, was adsorbed onto 4$\mu$ m-thick nanocrystalline $\mathrm{TiO}_{2}$ films ${ }^{9,10}$ from dilute $(8 \mu \mathrm{M})$ ethanol solution containing $30 \mathrm{mM}$ chenodeoxycholic acid. The dye coverage was kept low to make the cells almost transparent in the 'off' state; the coadsorbate, chenodeoxycholic acid, was used to 


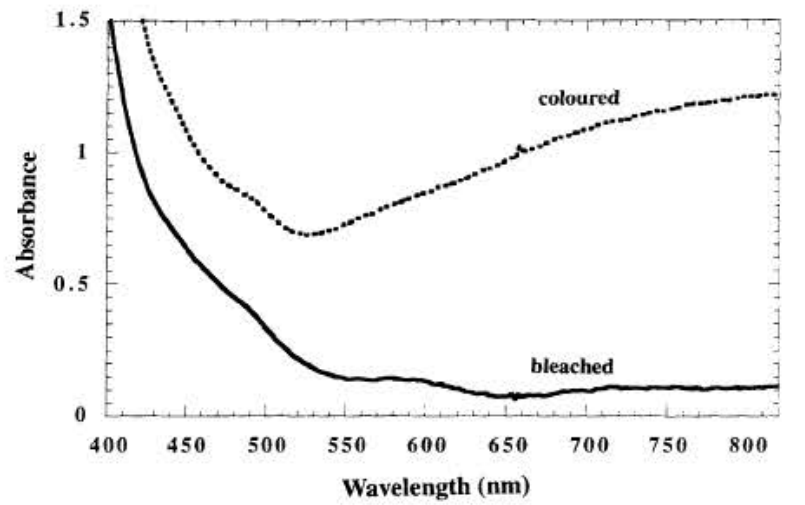

FIG. 1 Absorption spectra of a PEC cell before (bleached) and after (coloured) illumination at an intensity of $\sim 75 \mathrm{~mW} \mathrm{~cm}^{-2}$ for $1 \mathrm{~min}$. The absorption maximum of the dye occurs at $480 \mathrm{~nm}$ but is partially obscured by scattering from the $\mathrm{TiO}_{2}$ electrode. The tungsten bronze $\left(\mathrm{Li}_{x} \mathrm{WO}_{3}\right)$ that is responsible for most of the absorbance in the coloured state has a broad absorption maximum around $1,000 \mathrm{~nm}$.

increase the photocurrent efficiency ${ }^{12}$. The counter electrode was prepared by thermal evaporation of a 500 -nm-thick layer of $\mathrm{WO}_{3}$ onto an indium-tin oxide coated glass substrate. The two electrodes were bonded to each other around their periphery with $30-\mu \mathrm{m}$ thick strips of Surlyn 1601. The gap between the electrodes was filled, through small holes drilled in the $\mathrm{WO}_{3}$ electrode, with propylene carbonate containing $0.1 \mathrm{M} \mathrm{LiI}$ and $0.01 \mathrm{M} 4-t$ butylpyridine. The fill holes were then sealed with epoxy cement. Cells were fabricated ranging in size from 1 to $25 \mathrm{~cm}^{2}$.

Light absorption by the sensitizing dye leads to electron injection into the $\mathrm{TiO}_{2}$ film, with aquantum yield at short circuit of $\sim 70 \%$. This is followed by re-reduction of the oxidized dye via electron transfer from $\mathrm{I}^{-}$in solution. At open circuit, the dyesensitization process produces a photovoltage of $0.6-0.9 \mathrm{~V}$ but does not result in coloration of the cell. When the electrodes are short-circuited, however, the electrons move from the $\mathrm{TiO}_{2}$ through the external circuit to the $\mathrm{WO}_{3}$ film where, in the presence of cations small enough to intercalate into the $\mathrm{WO}_{3}$ lattice, a bluish-coloured tungsten bronze is formed. When the cation is $\mathrm{Li}^{+}$, for example, the reaction leading to coloration of the $\mathrm{WO}_{3}$ film is ${ }^{13}$

(transparent) $\mathrm{WO}_{3}+x \mathrm{Li}^{+}+x \mathrm{e}^{-} \leftrightarrow \mathrm{Li}_{\mathrm{x}} \mathrm{WO}_{3}$ (coloured)

The electrochromic process is highly reversible and lifetimes of over $10^{7}$ cycles have been achieved in display applications ${ }^{3}$. The coloration process is equivalent to charging a battery; the photovoltage generated by the dye-sensitized electrode is used to drive $\mathrm{Li}$ ions and electrons into the $\mathrm{WO}_{3}$ film. When the light is blocked after the $\mathrm{WO}_{3}$ electrode is charged, a voltage equal to the open circuit photovoltage, but of opposite polarity, appears across the PEC cell. If the electrodes are then short-circuited, this voltage causes the cell to discharge spontaneously back to its bleached state. If the electrodes are opened before the incident light is blocked, the cell remains coloured because the electrons cannot escape from the reduced $\mathrm{WO}_{3}$ film. Figure 1 shows the absorption spectra of a PEC cell before and after illumination for $1 \mathrm{~min}$ at $\sim 75 \mathrm{~mW} \mathrm{~cm}^{-2}$ intensity (comparable to noon daylight at sea level, $45^{\circ}$ latitude), illustrating the bleached and the coloured states, respectively.

Photographs of a $25-\mathrm{cm}^{2}$ cell in bleached, coloured and inhomogeneously coloured states are shown in Fig. 2 . When the electrolyte layer is thin ( $\sim 25 \mu \mathrm{m}$ in our examples) compared to the size of the cell, spatially resolved coloration occurs when just part of the cell is illuminated. Lateral ion mobility in the electrolyte limits the spatial resolution of the device; however, once the $\mathrm{Li}$ ions are intercalated into the $\mathrm{WO}_{3}$ film, their lateral mobility becomes so small that an image can be stored for many hours. Figure $2 c$ shows an example where only part of the device was illuminated. The unexposed part remained transparent whereas the illuminated part became coloured. The pattern was still visible after storage of the device with open-circuited terminals for more than $24 \mathrm{~h}$. The rate of colouring and bleaching of a cell on exposure to chopped white light of $\sim 75 \mathrm{~mW} \mathrm{~cm}^{-2}$ intensity was probed by measuring the transmission of a weak laser beam at $788 \mathrm{~nm}$ wavelength (Fig. 3). On illumination, the transmission decreased to its saturation level after $\sim 100 \mathrm{~s}$. Recovery to the bleached state after the light was blocked was somewhat slower.

The PEC devices appear to have advantages over earlier designs of 'smart' windows ${ }^{3,5.6}$. Use of smart windows can significantly decrease the air-conditioning costs in commercial buildings ${ }^{6}$. However, existing smart windows require an external power source to change the transmittance, making the retro-fitting of existing buildings difficult and expensive. A self-powered smart window, which uses the energy of the incident sunlight to modulate its own transmissivity, could be easily installed in existing buildings without requiring additional electrical connections. One recently proposed approach is a photovoltaic-electrochromic window consisting of a thin-film amorphous silicon carbide photovoltaic cell connected in tandem with an electrochromic window ${ }^{6,14}$. It consists of eight sequentially deposited layers that must be extremely thin in order for the device to be semitransparent. Unfortunately, electrical short-circuits are a serious problem and it has proved difficult to demonstrate a large-area device. Dye-sensitized electrodes have several distinct advantages over conventional photovoltaic cells, or other semiconductor electrodes, for large-area window or display applications. The PEC cells described here are remarkably simple devices that are easily assembled without electrical short-circuits. The light-absorbing dye layer can be made optically thin by either reducing the thickness of the $\mathrm{TiO}_{2}$ layer or by decreasing the concentration of the adsorbed dye. On the other hand, decreasing the optical thickness of inorganic semiconductor films often leads to electrical short-circuits. Inorganic semiconductors absorb all wavelengths that correspond to energies greater than their bandgap, and thus can be transparent only if the bandgap lies in the ultraviolet range. In contrast, sensitizing dyes of any colour, even infrared-absorbing dyes, can be employed for dye-sensitized

FIG. 2 Photographs of a PEC cell with a $25 \mathrm{~cm}^{2}$ active area. $a$, The bleached state. The cell is light yellow owing to the sensitizing dye and some scattering from the $\mathrm{TiO}_{2}$ electrode. $b$, The uniformly coloured state achieved by illumination at an intensity of $\sim 75 \mathrm{~mW} \mathrm{~cm}^{-2}$ for $1 \mathrm{~min}$. The colour is dark blue. c, The inhomogeneously coloured state achieved by illumination with one corner of the cell masked. The states shown in $b$ and $c$ remain approximately unchanged for at least $24 \mathrm{~h}$ if the cell is kept at open circuit.

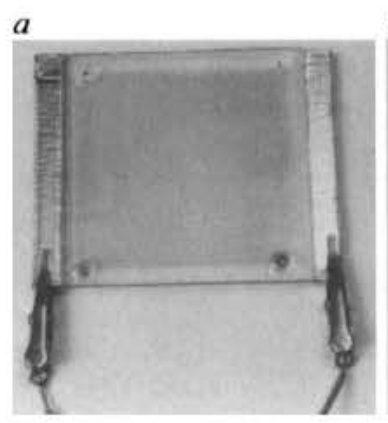

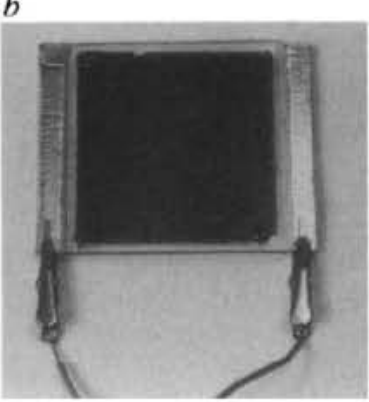

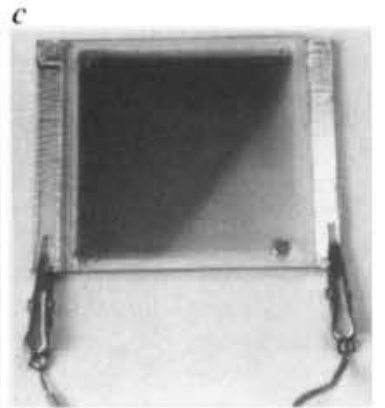




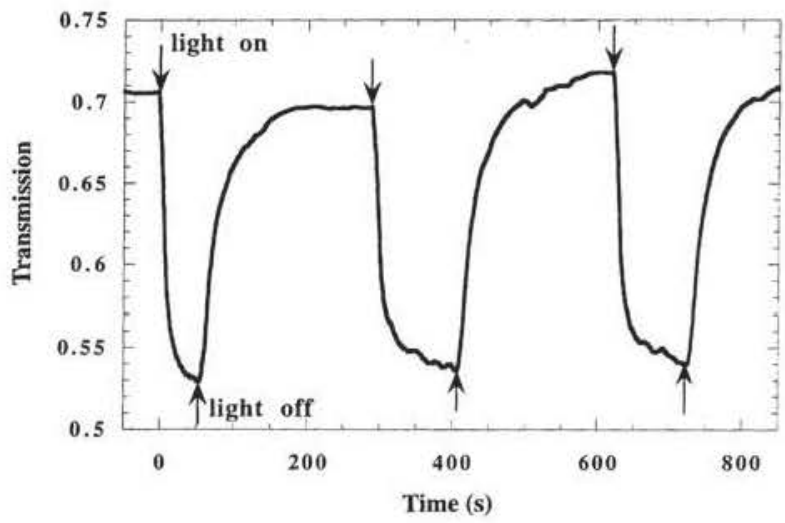

FIG. 3 Change in transmission at $788 \mathrm{~nm}$ wavelength of a short-circuited PEC cell exposed to chopped white light.

electrodes. In the latter case, the device would be transparent to visible light in the 'off' state but could be darkened by sunlight or addressed with an infrared diode laser. Perhaps most importantly, the dye-sensitized electrodes are inexpensive, robust and can be easily scaled up to give large-area substrates.

\footnotetext{
1. Dür, H. \& Bouas-Laurent, H. Photochromism: Molecules and Systems (Elsevier, Amsterdam, 1990).

2. Yao, J. N., Hashimoto, K. \& Fujishima, A. Nature 355, 624-626 (1992).

3. Deb, S. K. Sol. Energy Mater. Sol, Cells 25, $327-338$ (1992).

4. Green, M. Smith, W. C. \& Weiner, J. A. Thin Solid Films 38, 89-100 (1976).

4. Green, M., Smith, W. C. \& Weiner, J. A. Thin Solid Films 38,

5. Granqvist, C. G. Solid State Mater. Scl. 16, 291-308 (1990).

6. Benson, D. K. \& Branz, H. M. Sol, Energy Mater. Sol, Cells 39, 203-211

8. Deb, S. K. Appl. Opt. Suppl. 3, 192-195 (1969).

9. O'Regan, B. \& Grätzel, M. Nature 353, 737-740 (1991).

10. Nazeeruddin. M. K. et al. J. Am. Chem. Soc. 115, 6382-6390 (1993).

11. Parkinson, B. A. \& Spitler, M. T. Electrochim. Acta 37, 943-948 (1992).

12. Kay, A. \& Grätzel, M. J. Phys. Chem. 97, 6272-6277 (1993).

13. Faughnan, B. W. Crandall, R. S. \& Heyman, P. M. RCA Rev, 36, 177-197 (1975).

14. Bechinger, C. et al. J. Appl. Phys. 80, 1226-1232 (1996).

15. Bonhôte, P. et al. Chem Commun. 1163-1164 (1996).

16. DeBerry, D. W. \& Viehbeck, A. J. Electrochem. Soc. 130, 249-251 (1983).
}

ACKNOWLEDGEMENTS. We thank S.-Y. Huang for technical assistance and helpful discussions; this work was supported by the US Department of Energy. We thank the following for support: the Office of Energy Research, Division of Basic Energy Sciences, Advanced Energy Projects Division (C.B., S.F.); the Office of Energy Efficiency and Renewable Energy, Office of Utility Technologies, Photovoltaics Division (A.Z.); and the Office of Energy Research, Division of Basic Energy Sciences, Chemical Sciences Division (J.S., B.G.)

CORRESPONDENCE and requests for materials should be addressed to B.A.G. (e-mail: bgregg@nrel. nrel.gov) 